\title{
The inflammatory effects of UDP-glucose in N9 microglia are not mediated by $\mathrm{P} 2$ Y14 receptor activation
}

Vielska M. Brautigam • George R. Dubyak •

Jessica M. Crain - Jyoti J. Watters

Published online: 30 April 2008

(C) Springer Science + Business Media B.V. 2008

Erratum to: Purinergic Signalling

DOI 10.1007/s11302-008-9095-1

The correct affiliations of Jyoti J. Watters should be:

Department of Comparative Biosciences and Program in Molecular and Cellular Biology, University of Wisconsin, Madison, WI 53706

The article was published in Volume 4 Issue 1 pp. 73-78.

The online version of the original article can be found at: http://dx.doi.org/10.1007/s11302-008-9095-1.

V. M. Brautigam · J. J. Watters $(\bowtie)$

Department of Comparative Biosciences,

University of Wisconsin, 2015 Linden Dr.,

Madison, WI 53706, USA

e-mail: jjwatters@wisc.edu

G. R. Dubyak

Department of Physiology and Biophysics,

Case Western Reserve University,

Cleveland, $\mathrm{OH}$, USA

J. M. Crain · J. J. Watters

Program in Molecular and Cellular Biology,

University of Wisconsin,

Madison, WI 53706, USA 